\title{
Silicon anode for rechargeable aqueous lithium-air batteries
}

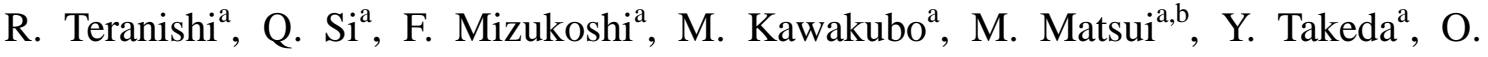 \\ Yamamoto $^{\mathrm{a}, *}$, N. Imanishi ${ }^{\mathrm{a}}$ \\ ${ }^{a}$ Graduate School of Engineering, Mie University, Tsu, Mie, 514-8507, Japan \\ ${ }^{b}$ JST, PRESTO, 4-1-8-Honcho, Kawaguchi, Saitama, 332-0012, Japan
}

Keywords: High energy density battery, Lithium-air battery, Silicon anode, Polyimide binder,

\begin{abstract}
A novel aqueous lithium-air rechargeable cell with the configuration of $\mathrm{Si} / 1 \mathrm{M} \mathrm{LiClO} 4$ in ethylene carbonate-diethylene carbonate $/ \mathrm{Li}_{1+\mathrm{x}+\mathrm{y}} \mathrm{Al}_{\mathrm{x}}(\mathrm{Ti}, \mathrm{Ge})_{2-\mathrm{x}} \mathrm{P}_{3-\mathrm{y}} \mathrm{Si}_{\mathrm{y}} \mathrm{O}_{12} / 5 \mathrm{M} \mathrm{LiCl}-1 \mathrm{M}$ $\mathrm{LiOH}$ aqueous solution/carbon black, air is proposed. A silicon anode composed of mechanically milled silicon power with an average particle size of $c a .0 .5 \mu \mathrm{m}$, vapor grown carbon fiber and a polyimide binder was examined. The open-circuit voltage at the charged state was $2.9 \mathrm{~V}$ at $25^{\circ} \mathrm{C}$. The discharge capacity of $700 \mathrm{mAh}$ g-silicon ${ }^{-1}$ was retained for 40 cycles at $0.3 \mathrm{~mA} \mathrm{~cm}^{-2}$ with cut-off voltages of 3.5 and $1.5 \mathrm{~V}$. Significant capacity fade was observed at deep charge and discharge cycling at $2000 \mathrm{mAh}$ g-silicon ${ }^{-1}$.
\end{abstract}

\section{Introduction}

Lithium-air rechargeable batteries are attracting increased attention for application in electrical vehicles (EVs) because of their extremely high specific mass energy density compared to lithium-ion batteries [1-4]. The calculated specific mass and volume energy densities including oxygen (discharge state) are $3458 \mathrm{Wh} \mathrm{kg}^{-1}$ and $4471 \mathrm{Wh} \mathrm{L}^{-1}$, and those excluding oxygen (charged state) are $11429 \mathrm{Wh} \mathrm{kg}^{-1}$ and $6103 \mathrm{Wh} \mathrm{L}^{-1}$, respectively, for a non-aqueous system. The aqueous system shows lower energy density of $1917 \mathrm{Wh} \mathrm{kg}^{-1}$ and $2895 \mathrm{Wh} \mathrm{L}^{-1}$ for the discharged state, and $2369 \mathrm{Wh} \mathrm{kg}^{-1}$ and $2010 \mathrm{Wh} \mathrm{L}^{-1}$ for the charged state. These energy densities are much higher than those of $387 \mathrm{Wh} \mathrm{kg}^{-1}$ and $1016 \mathrm{Wh} \mathrm{L}^{-1}$ for conventional lithium-ion batteries with a carbon anode and $\mathrm{LiCoO}_{2}$ cathode [2]. The energy density calculations for lithium-air batteries are based on the masses and volumes of lithium metal, the reaction product,

*Correspondence author. Tel: +81-59-231-9420; Fax: +81-59-231-9478

E-mail address: Yamamoto@chem.mie-u.ac.jp (O.Yamamoto) 
oxygen, and water, assuming the following reactions and open-circuit voltages (OCV) of $2.96 \mathrm{~V}$ [5] for the non-aqueous system

$$
2 \mathrm{Li}+\mathrm{O}_{2}=\mathrm{Li}_{2} \mathrm{O}_{2},
$$

and of $3.0 \mathrm{~V}[6]$ for the aqueous system

$$
4 \mathrm{Li}+6 \mathrm{H}_{2} \mathrm{O}+\mathrm{O}_{2}=4 \mathrm{LiOH} \cdot \mathrm{H}_{2} \mathrm{O} .
$$

The cycling efficiency for lithium deposition and stripping is less than $100 \%$; therefore, lithium should be in excess and charged threefold [7]. The calculated energy density is decreased by the excess lithium charge. The specific energy densities of the non-aqueous system with threefold excess lithium are $2154 \mathrm{~kW} \mathrm{~kg}^{-1}$ and $1769 \mathrm{~kW} \mathrm{~L}^{-1}$ for the discharged state, and $3810 \mathrm{Wh} \mathrm{kg}^{-1}$ and $2034 \mathrm{Wh} \mathrm{L}^{-1}$ for the charged state. For the aqueous system, the specific energy densities are $1440 \mathrm{Wh} \mathrm{kg}^{-1}$ and $1496 \mathrm{Wh} \mathrm{L}^{-1}$ for the discharged state, and $1680 \mathrm{Wh} \mathrm{kg}^{-1}$ and $1218 \mathrm{Wh} \mathrm{L}^{-1}$ for the charged state. The specific mass energy density of the cell with threefold excess lithium is still significantly higher than that for conventional lithium-ion batteries, but the specific volume energy density is not so attractive. The volumetric energy density is important for EVs; therefore, improvement of the lithium metal electrode cycling efficiency or replacement of the lithium electrode with an alternative is an important challenge to increase the volume specific energy density of lithium-air batteries. The non-aqueous system has higher energy density than the aqueous system, but the non-aqueous system has some severe problems that must still be addressed, such as lithium corrosion by water from the air, electrolyte decomposition and high overpotential. These problems with the non-aqueous system could be overcome for the aqueous system [1].

Silicon is an attractive anode material for lithium batteries because of its high theoretical capacity (4199 $\mathrm{mAh} \mathrm{g}^{-1}$ as $\mathrm{Li}_{4.4} \mathrm{Si}$ ) and low lithium insertion potential as well as lithium dendrite formation free [8-10]. The specific energy densities for aqueous lithium air-batteries with a silicon anode are calculated from the following cell reaction with OCV of $2.9 \mathrm{~V}$ :

$$
(4 / 4.4) \mathrm{Li}_{4.4} \mathrm{Si}+6 \mathrm{H}_{2} \mathrm{O}+\mathrm{O}_{2}=4\left(\mathrm{LiOH} \cdot \mathrm{H}_{2} \mathrm{O}\right)+(4 / 4.4) \mathrm{Si}
$$

The specific energy densities are $1608 \mathrm{Wh} \mathrm{kg}^{-1}$ and $2547 \mathrm{Wh} \mathrm{L}^{-1}$ for the discharged state, and $1927 \mathrm{Wh} \mathrm{kg}^{-1}$ and $2029 \mathrm{Wh} \mathrm{L}^{-1}$ for the charged state. The mass specific energy density is more than three times and the volume energy density two times higher than those of conventional lithium-ion batteries. However, the use of a commercial silicon 
anode for lithium-ion batteries has been hindered by the large volume change of over $300 \%$ during lithium-alloying and extraction, which results in the generation of an enormous amount of mechanical stress within the electrode [11]. Many approaches have been proposed to overcome these problems, such as using silicon nanostructural materials [12], silicon based composites [13-15], and a selection of binders [16]. Recently, Kim et al. reported the effect of a binder for the silicon anode and determined that a polyimide (PI) binder provided more stability and recuperative capacity against mechanical stress than the conventional polyvinylidine difluoride (PVdF) binder [17]. In this study, the possible of a silicon anode for aqueous lithium-air batteries is examined, where the silicon anode consists of a conventional mechanically milled silicon powder with a particle size of approximately $0.5 \mu \mathrm{m}$ and the rigid PI binder.

\section{Experimental}

The silicon anode was prepared according to the following procedure. Silicon powder (average particle size of $0.5 \mu \mathrm{m}$, Kinsei Matec Ltd., Japan) was mixed with a conductive additive of vapor grown carbon fiber (VGCF; average $0.15 \mu \mathrm{m}$ diameter and $20 \mu \mathrm{m}$ long, CA-JP 200, Showa Denko Ltd. Japan) and a polyamic acid solution in $\mathrm{N}$-methyl-2-pyrroliddone (NMP) (20 wt\%) (Toray Ltd. Japan). The slurry was cast onto a copper foil. The cast silicon electrode was dried at $80{ }^{\circ} \mathrm{C}$ for $30 \mathrm{~min}$, uniaxially pressed at $100 \mathrm{MPa}$, heated to $350^{\circ} \mathrm{C}$ for $1 \mathrm{~h}$ and kept at $350{ }^{\circ} \mathrm{C}$ for $1 \mathrm{~h}$, and then cooled to room temperature for $1 \mathrm{~h}$ under vacuum. The thickness of the silicon electrode was approximately $50 \mu \mathrm{m}$.

The performance of the silicon electrode with various weigh ratios of VGCF and PI binder was tested using a coin-type $\mathrm{Si} /$ non-aqueous electrolyte/Li half-cell to optimize the ratio of the components, where $1 \mathrm{M} \mathrm{LiClO}_{4}$ in ethylene carbonate-diethyl carbonate (EC-DEC) (1:1 volume ratio) and $1 \mathrm{M} \mathrm{LiPF}_{6}$ in fluoroethylene carbonate (FEC)-dimethyl carbonate (DMC) (4:6 volume ratio) were used as the non-aqueous electrolyte. A silicon-air full cell was constructed using the silicon electrode, a water-stable lithium ion conducting solid electrolyte of $\mathrm{Li}_{1+x+y} \mathrm{Al} x(\mathrm{Ti}, \mathrm{Ge})_{2-\mathrm{x}} \mathrm{P}_{3-\mathrm{y}} \mathrm{Si}_{\mathrm{y}} \mathrm{O}_{12}$ (LTAP; $150 \mu \mathrm{m}$ thick and $19 \mathrm{~mm}$ diameter, Ohara Ltd. Japan), and a carbon black air electrode. A schematic diagram of the cell is shown in Fig. 1. The electrical conductivity of the LTAP plate was $1 \times 10^{-4} \mathrm{~S} \mathrm{~cm}^{-1}$ at room temperature. The air electrode consisted of 
a reaction layer and an air diffusion layer. The reaction layer was prepared by mixing Ketjen black (KB, EC600JD, specific surface area of $1400 \mathrm{~m}^{2} \mathrm{~g}^{-1}$, Akzo Noble, Netherlands) and polytetrafluoroethylene (PTFE, Daikin Kogyo Ltd, Japan). The weight ratio of KB:PTFE was 95:5 and the weight of $\mathrm{KB}$ was approximately $60 \mathrm{mg}$. The mixture was dried at $80{ }^{\circ} \mathrm{C}$ and pressed onto a Ti mesh (100 mesh) with a carbon paper gas diffusion layer (Sigracet, SGL Co. Germany) under pressure at $64 \mathrm{MPa}$. The electrolyte at the silicon electrode side was $1 \mathrm{M} \mathrm{LiClO}_{4}$ in EC-DEC and that at the air electrode side was an aqueous solution of $5 \mathrm{M} \mathrm{LiCl} / 1 \mathrm{M} \mathrm{LiOH}$. The contact area of the silicon electrode with the electrolyte was $1.1 \mathrm{~cm}^{2}$ and the current densities were calculated using the contact area. The contact area of the air electrode with the electrolyte was $0.50 \mathrm{~cm}^{2}$. The silicon electrode with the electrolyte was assembled in an argon-filled glove box. The cells were galvanostatically charged and discharged at $25{ }^{\circ} \mathrm{C}$ using a battery cycler (BTS $2004 \mathrm{H}$, Nagano Ltd, Japan). The electrode was examined using scanning electron microscopy (SEM S-4000, Hitachi Ltd, Japan) and the particle size distribution was determined using a laser diffraction particle analyzer (Micrometer MT 3300 EXII, Nikkiso Ltd, Japan).

\section{Results and discussion}

Nanostructural silicon has been reported to exhibit good cycling performance; however, a less expensive and conventional mechanically-milled silicon powder with average particle size of $0.5 \mu \mathrm{m}$ was used in this study, because cost performance is an important requirement for EV applications. Figure 2 shows an SEM image and the particle size distribution of the silicon powder. The SEM image shows that small sized silicon particles $(c a .0 .5 \mu \mathrm{m})$ are aggregated. The particle size distribution profile shows that the size of the aggregated particles is approximately $40 \mu \mathrm{m}$, where the cumulative percentage was counted with respect to the volume of particles. The hard PI binder was selected to mitigate the physical volume change during the insertion and extraction of lithium ions into and from the silicon electrode [17]. The charge and discharge performance of the silicon anode was examined using coin-type cells of $\mathrm{Si} / 1 \mathrm{M} \mathrm{LiPF}_{6}$ in FEC-DMC/Li and $\mathrm{Si} / 1 \mathrm{M} \mathrm{LiClO}_{4}$ in EC-DEC/Li. Various ratios of silicon powder ( $\mathrm{Si}$ ), binder (PI) and the conductive additive were examined. As the conductive additive, VGCF, acetylene black (Denki Kagaku, Japan) and a mixture of both were tested. VGCF showed better first charge and discharge coulombic efficiency than acetylene 
black and the mixture of acetylene black and VGCF (1:1 wt ratio). An optimum weight ratio of Si/PI/VGCF for cyclic performance was determined to be 55/25/20. Choi et al. [18] reported that the addition of FEC into $\mathrm{LiPF}_{6}$ in EC-DEC improved the discharge capacity retention and coulombic efficiency of a silicon thin film electrode. The discharge capacity retention of $\mathrm{Si}$ for the $\mathrm{Si} / 1 \mathrm{M} \mathrm{LiPF}_{6}$ in FEC-DMC/Li cell was improved, but the cell resistance of the lithium-air full cell with the LTAP separator was as high as $60 \mathrm{k} \Omega$. This high cell resistance may be due to reaction between LTAP and FEC. Therefore, the $1 \mathrm{M} \mathrm{LiClO}_{4}$ in EC-DEC electrolyte and a silicon anode with 55 wt $\% \mathrm{Si}, 25 \mathrm{wt} \% \mathrm{PI}$ and $20 \mathrm{wt} \%$ VGCF were used for the following experiments

Figure 3 shows the charge and discharge curves as a function of cycling, and the silicon electrode capacity change by cycling for the coin type $\mathrm{Si} / 1 \mathrm{M} \mathrm{LiClO}_{4}$ in EC-DEC/Li cell at $25{ }^{\circ} \mathrm{C}$ and $0.24 \mathrm{~mA} \mathrm{~cm}^{-2}\left(101 \mathrm{~mA} \mathrm{~g}^{-1}\right)$, where the cut-off voltages were $0 \mathrm{~V}$ for lithium insertion into silicon and $1.5 \mathrm{~V}$ for lithium extraction from the silicon electrode, and with a silicon loading of $2.68 \mathrm{mg}$. The capacity is presented per gram of silicon in the composite electrode. The initial charge and discharge capacities were 3700 and $2838 \mathrm{mAh} \mathrm{g}^{-1}$, and those at the second cycle 3007 and $2908 \mathrm{~mA} \mathrm{~g}^{-1}$, respectively. The coulombic efficiencies at the first and second cycles were 77 and 97\%, respectively. Kim et al. [17] reported the lithium insertion and extraction properties of a surface modified silicon electrode using PI as a binder, and the second cycle charge and discharge capacities were 2274 and $2175 \mathrm{mAh} \mathrm{g}^{-1}$ at a current density of $200 \mathrm{~mA} \mathrm{~g}^{-1}$, respectively. In addition, Choi et al. [18] found that the initial coulombic efficiency was improved from $28.9 \%$ for a silicon electrode with the PVdF binder to $74.9 \%$ by introduction of the high tensile strength polyamide imide binder. The present results also suggest that the PI binder is effective to improve the cycling performance of the silicon electrode. Degradation of the discharge capacity by cycling is not significant. The discharge capacity was $2447 \mathrm{mAh} \mathrm{g}^{-1}$ and the coulombic efficiency for the charge and discharge capacity was $94 \%$ at the $10^{\text {th }}$ cycle. The specific area capacity from the product of the specific capacity per gram of silicon and the silicon loading per area is $6.0 \mathrm{mAh} \mathrm{cm}^{-2}$ at the $10^{\text {th }}$ cycle. The specific area capacity can be used as a more practical parameter to optimize the performance of the electrode in practical lithium air cells [20].

The silicon anode with PI binder showed excellent performance as the lithium electrode. The possibility of a silicon anode for the aqueous lithium-air rechargeable cell was examined using a KB air electrode. A good catalytic activity for oxygen evolution 
and reduction for the $\mathrm{KB}$ air electrode was achieved at $0.2 \mathrm{~mA} \mathrm{~cm}^{2}$ [21]. Figure 4 shows

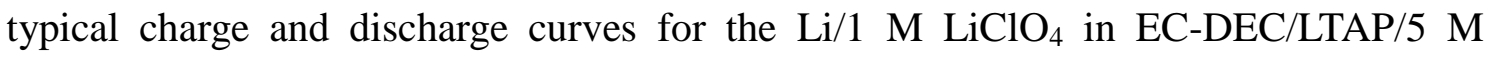
LiCl-1 M LiOH aqueous solution/KB, air cell at $25{ }^{\circ} \mathrm{C}$ and $0.34 \mathrm{~mA} \mathrm{~cm}{ }^{-2}$, with approximately $0.06 \mathrm{~g} \mathrm{~KB}$ loading and the capacity was denoted according to the gram weight of $\mathrm{KB}$ in the air electrode. A sufficient amount of the $5 \mathrm{M} \mathrm{LiCl} / 1 \mathrm{M} \mathrm{LiOH}$ aqueous solution was employed, because LTAP is unstable in water and high concentrations of $\mathrm{LiOH}$, but is stable in an aqueous solution of $\mathrm{LiOH}$ with a high content of $\mathrm{LiCl}$ [22]. Steady cell potentials were observed for $120 \mathrm{mAh} \mathrm{g}^{-1}$, which corresponds to approximately $6.5 \mathrm{mAh} \mathrm{cm}^{-2}$. No charge-discharge voltage degradation was observed for 5 cycles, which suggests that the KB air electrode without a catalyst is acceptable to examine the silicon anode performance for the lithium-air rechargeable cell below an area specific capacity of $6.5 \mathrm{mAh} \mathrm{cm}^{-2}$ at $0.34 \mathrm{~mA} \mathrm{~cm}^{-2}$ in an aqueous solution with an excess amount of $5 \mathrm{M} \mathrm{LiCl}$ and $1 \mathrm{M} \mathrm{LiOH}$. The charge and discharge performance of the full cell with the silicon anode was examined using the KB air electrode. Figure 5 compares the impedance profiles of the $\mathrm{Si} / 1 \mathrm{M} \mathrm{LiClO}_{4}$ in EC-DEC/LTAP/5 $\quad \mathrm{M} \quad \mathrm{LiCl}-1 \quad \mathrm{M} \quad \mathrm{LiOH} / \mathrm{KB}$, air cell, $\mathrm{Li}_{4.2} \mathrm{Si} / 1 \quad \mathrm{M} \quad \mathrm{LiClO}_{4}$ in

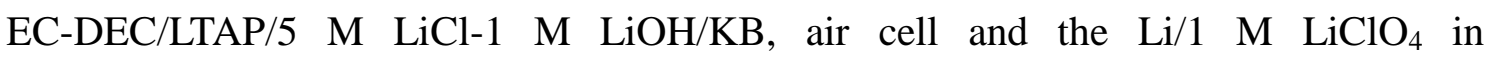
EC-DEC/LTAP/5 M LiCl-1 M LiOH/KB, air cell at $25{ }^{\circ} \mathrm{C}$. These profiles show two semicircles in the frequency range from $631 \mathrm{kHz}$ to $100 \mathrm{kHz}$ and from $100 \mathrm{kHz}$ to 100 $\mathrm{Hz}$. These semicircles may be due to the contribution of the electrolytes and the silicon (or lithium) electrode, because the contribution of the air electrode resistance is not significant [21]

. The semicircle in the high frequency range corresponds to the grain boundary resistance of the LTAP plate, which was confirmed by impedance measurements of a $\mathrm{Au} / \mathrm{LTAP} / \mathrm{Au}$ cell [22]. The second semicircle may correspond to the interface resistance with the charge transfer resistance at the silicon (or lithium) electrode and the resistance of the solid electrolyte interface (SEI) between silicon (or lithium) and the 1 $\mathrm{M} \mathrm{LiClO}_{4}$-EC-DEC electrolyte. The interface resistance of the silicon electrode is 47 $\Omega \mathrm{cm}^{2}$, which is lower than that of the lithium electrode at $57 \Omega \mathrm{cm}^{2}$. The interface resistance between lithium electrode and electrolyte is dependent on the electrolyte. A high interface resistance of $1000 \Omega \mathrm{cm}^{-1}$ at $35{ }^{\circ} \mathrm{C}$ was reported for the $\mathrm{Li} / \mathrm{LiPF} 6$ in EC-DEC-EMC/Li cell $[23]$ and a low interface resistance of $150 \Omega \mathrm{cm}^{-2}$ at $30{ }^{\circ} \mathrm{C}$ for the Li/tetraglime- $\mathrm{Li}\left(\mathrm{CF}_{3} \underline{\mathrm{SO}}_{2} \underline{2}_{2} \underline{\mathrm{N} / \mathrm{LiCoO}} 2\right.$

Figure 6 shows charge and discharge profiles for the $\mathrm{Si} / 1 \mathrm{M} \mathrm{LiClO}_{4}$ in 
EC-DEC/LTAP/5 M LiCl-1 M LiOH/KB, air cell at $25^{\circ} \mathrm{C}$ and $0.272 \mathrm{~mA} \mathrm{~cm}{ }^{-2}$, where the cell was charged to $4000 \mathrm{mAh} \mathrm{g}^{-1}$ and then discharged to $1.5 \mathrm{~V}$. After the $2^{\text {nd }}$ cycle, the cell was charged and discharged under a cut-off voltage of $3.5 \mathrm{~V}$ for charging and $1.5 \mathrm{~V}$ for discharging. The OCV of the charged cell was $2.9 \mathrm{~V}$, which is slightly lower than that reported previously for the aqueous lithium air cell with a lithium anode [6]. In the first charging process, lithium ions are supplied from the aqueous electrolyte through the LTAP separator and lithium is deposited on the silicon electrode to make a silicon alloy, while oxygen is evolved at air electrode [21], where the excess amount of aqueous electrolyte was charged. The charge and discharge overpotentials for the cell with the silicon anode were slightly higher than those for the cell with the lithium metal anode shown in Fig. 4. The discharge capacity of the cell was significantly decreased with cycling. The degradation of the capacity is caused by the silicon electrode side, because no degradation in capacity under the same charge and discharge conditions was observed for the cell with a lithium anode (Fig. 4). The degradation in capacity with cycling could be explained by the large volume change of the silicon electrode. The silicon electrode in the coin-type cell was pressed with a spring to absorb the volume change, but that in the lithium-air cell was not pressed. To suppress the volume change by deep charge and discharge, the cyclic performance was examined under a limited condition of the capacity. Figure 7 shows the cycling performance of the $\mathrm{Si} / 1 \mathrm{M} \mathrm{LiClO}_{4}$ in EC-DEC/LTAP/5 M LiCl-1 M LiOH/KB, air cell at $25{ }^{\circ} \mathrm{C}$ under controlled discharge capacity. The cells were charged to $4000 \mathrm{mAh} \mathrm{g}^{-1}$ and then cycled at discharge capacities of 2000, 1500, 1000, and $700 \mathrm{mAh} \mathrm{g}^{-1}$. The discharge cell voltages were gradually decreased with cycling. Figure 8 shows the change in discharge capacity by cycling at a cut-off discharge voltage of $1.5 \mathrm{~V}$ as a function of the discharge capacity after the second cycle. The discharge capacity is decreased with cycling. To develop a high specific energy density lithium-air battery of $400 \mathrm{Wh} \mathrm{kg}^{-1}$, the area specific energy density should be more than $7 \mathrm{mAh} \mathrm{cm}^{-2}$ [25]. The amounts of silicon for the cells with discharge capacities of 2000 and $700 \mathrm{mAh} \mathrm{g}^{-1}$ were 3.25 and $3.05 \mathrm{mg} \mathrm{cm}^{-2}$, respectively, which correspond to 6.50 and $2.13 \mathrm{mAh} \mathrm{cm}^{-2}$, respectively. The area specific capacity of $6.50 \mathrm{mAh} \mathrm{cm}^{-2}$ at $2000 \mathrm{mAh} \mathrm{g}^{-1}$ is acceptable, but the cyclic performance is quite poor. Therefore, the cell should be designed to absorb the volume change of silicon electrode during the charge and discharge process as observed for the coin-type cell.

\section{Conclusion}


Commercial silicon powder with an average particle size of $c a .0 .5 \mu \mathrm{m}$ was used with a hard PI binder as the anode for a rechargeable aqueous lithium-air cell. The silicon electrode exhibited high reversible capacity and stable cyclability at a charge and discharge current density of $0.24 \mathrm{~mA} \mathrm{~cm}^{-2}\left(101 \mathrm{~mA} \mathrm{~g}^{-1}\right)$ in a coin type half-cell of $\mathrm{Si} / 1$ $\mathrm{M} \mathrm{LiClO}_{4}$ in EC-DEC/Li. The silicon electrode was evaluated as a possible anode for the aqueous lithium-air rechargeable cell with the composition $\mathrm{Si} / 1 \mathrm{M} \mathrm{LiClO}_{4}$ in EC-DEC/LTAP/5 M LiCl-1 M LiOH/KB, air. The cell was successfully charged to 4000 $\mathrm{mA} \mathrm{g}^{-1}$ at $0.272 \mathrm{~mA} \mathrm{~cm}^{-1}$ with a low over-potential. However, the cyclic performance was poor. The first cycle discharge capacity of $2160 \mathrm{mAh} \mathrm{g}^{-1}$ was decreased to $860 \mathrm{mAh}$ $\mathrm{g}^{-1}$ at the $5^{\text {th }}$ cycle. The large capacity fade with cycling could be explained by the volume change of the silicon anode during the charge and discharge processes without external pressure applied to the silicon electrode. Thus, the cyclic performance could be improved by developing a cell with pressure applied to the silicon electrode as with the coin-type cell.

\section{Acknowledgment}

This study was supported by the Japan Science and Technology Agency (JST) under the "Advanced Low Carbon Technology Research and Development Program".

\section{References}

[1] N. Imanishi, O. Yamamoto, Materials Today 17 (2014) 24

[2] P.G. Bruce, S.A. Freunberger, L.J. Hardwicik, J.-M. Tarascon, Nature Mater. 11 (2012) 19

[3] G. Girishkumar, B. McCloskey, A.C. Luntz, S. Swanson, W. Wilcke, Phys. Chem. Lett. 1 (2010) 2193

[4] M. Armand, J.-M. Tarascon, Nature 451 (2008) 642

[5] M.W. Chase J. J. Phys. Chem. Ref, Data Monograph 9 (1990) 1510

[6] N. Imanishi, O. Yamamoto, in B. Scrosati, K.M. Abraham, W. van Schalkwijk, J. Hassoun (eds.) Lithium Batteries: Advanced Technologies and Applications, ECS and Wiley, Hoboken, NJ, 2013

[7] J. Dahn, Scalable energy storage; beyond Li-ion, Almaden, San Jose CA, USA 2009 [8] B.A. Boukamp, O.C. Lesh, R.A. Huggins, J. Electrochem, Soc. 128 (1981) 725 
[9] M.N. Obrovac, L. Christensen, Electrochem. Solid State Lett. 7 (2004) A93

[10] S. Liu, N. Imanishi, T. Zhang, A. Hirano, Y.Takeda, O. Yamamoto, J Yand, J. Electrochem. Soc. 157 (2007) A1092

[11] C.M. Park, K.M. Kim, H. Kim, Y.J. Kim, H.-J.Sohn, Energy Enviro. Sci. 4 (2011) 1986

[12] J. Cho, J. Mater. Chem. 20 (2010) 4009

[13] R. Jeannie, S. Szczechm, Energy Enviro. Sci. 4 (2011) 56

[15] Q. Si, K. Hanai, T. Ichikawa, A, Hirano, N. Imanishi, O. Yamamoto, Y. Takeda, J. Power Sources 196 (2011) 6982

[16] Z. Chen, L.Christensen, J.R. Dahn, J. Electrochem. Soc. 150 (2003) 919

[17] J.S. Kim, W. Cho, K.Y. Cho, D. Byun, J. Lim, J.K. Lee, J. Power Sources 244 (2013) 521

[18] N.-S. Choi, K.H. Yew, K.Y. Lee, M. Sung, H. Kim. S.-S. Kim, J, Power Sources 167 (2006) 1254

[19] N.-S. Choi, K.H. Yew, W.-U. Choi, S.-S, Kim, J. Power Sources 177 (2008) 590

[20] J. Xiao, J. Electrochem. Soc. 157 (2010) A487

[21] H. Ohkuma, M.Matsui, O. Yamamoto, N. Imanishi, J. Power Sources 245 (2014) 947

[22] Y. Shimonishi, T. Zhang, N. Imanishi, D. Im, D.-J. Lee, A. Hirano, Y. Takeda, O. Yamamoto, N. Sammes, J. Power Sources 196 (2011) 5128

[23] H.E. Park, C.H. Hong, W.Y.Yoon, J. Power Sources 178 (2008) 765

[24] H. Yoshida, M.Nakamuram Y. Kazue, N.Tachikawa, S.Tuzuki, S/ Seki, K. Dokko, M. Watanabe, J. Am. Chem,. Soc., 135 (2011) 13121

[25] M.S. Park, S.B. Ma, D.J. Lee, D.J. Im, S.-D. Doo, O. Yamamoto, Scientific Report 4, (2014) 3815 


\section{Figure captions}

Fig. 1. Schematic diagram of the test cell.

Fig. 2. (a) SEM images and (b) particle size distribution of the mechanically milled silicon powder.

Fig. 3. (a) Charge-discharge curves and (b) cycling performance of the $\mathrm{Si} / 1 \mathrm{M} \mathrm{LiClO}_{4}$

in EC-DEC/Li coin-type cell at $25^{\circ} \mathrm{C}$ and $0.24 \mathrm{~mA} \mathrm{~cm}^{-2}$. Si loading was $2.68 \mathrm{mg}$.

Fig. 4. Charge-discharge curves for the $\mathrm{Li} / 1 \mathrm{M} \mathrm{LiClO}_{4}$ in EC-DEC/LTAP/5M LiCl-1 $\mathrm{M} \mathrm{LiOH} / \mathrm{KB}$, air cell at $25{ }^{\circ} \mathrm{C}$ and $0.34 \mathrm{~mA} \mathrm{~cm}^{-2}$. Si and $\mathrm{KB}$ loadings were 3.88 and 60 $\mathrm{mg}$, respectively.

Fig. 5. Impedance profiles of (a) $\mathrm{Si} / 1 \mathrm{M} \mathrm{LiClO}_{4}$ in EC-DEC/LTAP/5 M LiCl-1 M $\mathrm{LiOH} / \mathrm{KB}$, air, (b) $\mathrm{Li}_{4.2} \mathrm{Si} / 1 \mathrm{M} \mathrm{LiClO}_{4}$ in EC-DEC/LTAP/5 M LiCl-1 M LiOH/KB, air and (c) $\mathrm{Li} / 1 \mathrm{M} \mathrm{LiClO}_{4}$ in EC-DEC/LTAP/5 M LiCl-1 M LiOH/KB, air cells at $25^{\circ} \mathrm{C}$.

Fig. 6. Charge-discharge curves for the $\mathrm{Si}$ anode at $25^{\circ} \mathrm{C}$. The cell was charged to $4000 \mathrm{mAh} \mathrm{g}^{-1}$ at $0.272 \mathrm{~mA} \mathrm{~cm}^{-2}$ and then cycled in the cut-off voltage range of 1.5 to $3.5 \mathrm{~V}$. Si loading was $3.08 \mathrm{mg}$.

Fig.7. Charge-discharge curves for $\mathrm{Si} / 1 \mathrm{M} \quad \mathrm{LiClO}_{4}$ in EC-DEC/LTAP/5M LiCl-1MLiCl/KB, air at $25{ }^{\circ} \mathrm{C}$. The cell was charged to $4000 \mathrm{mAh} \mathrm{g}^{-1}$ and then cycled under limited capacity: (a) $2000 \mathrm{mAh} \mathrm{g}^{-1}$ at $0.32 \mathrm{~mA} \mathrm{~cm}^{-2},(\mathrm{Si}=3.58 \mathrm{mg})$, (b) 1500 $\mathrm{mAh} \mathrm{g}^{-1}$ at $0.32 \mathrm{~mA} \mathrm{~cm}^{-2}(\mathrm{Si}=3.69 \mathrm{mg})$, (c) $1000 \mathrm{mAh} \mathrm{g}^{-1}$ at $0.33 \mathrm{~mA} \mathrm{~cm}^{-2}(\mathrm{Si}=3.69$ $\mathrm{mg})$, and (d) $700 \mathrm{mAh} \mathrm{g}^{-1}$ at $0.30 \mathrm{~mA} \mathrm{~cm}^{-2}(\mathrm{Si}=0.336 \mathrm{mg})$.

Fig. 8. Discharge capacity vs. cycle curves for $\mathrm{Si} / 1 \mathrm{M} \mathrm{LiClO}{ }_{4}$ in EC-DEC/LTAP/5M

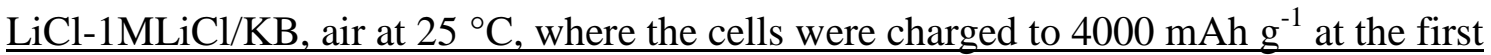
charge and cycled at a limited capacity. The discharge capacities were plotted at the cut-off voltage of $1.5 \mathrm{~V}$. 
Fig. 1

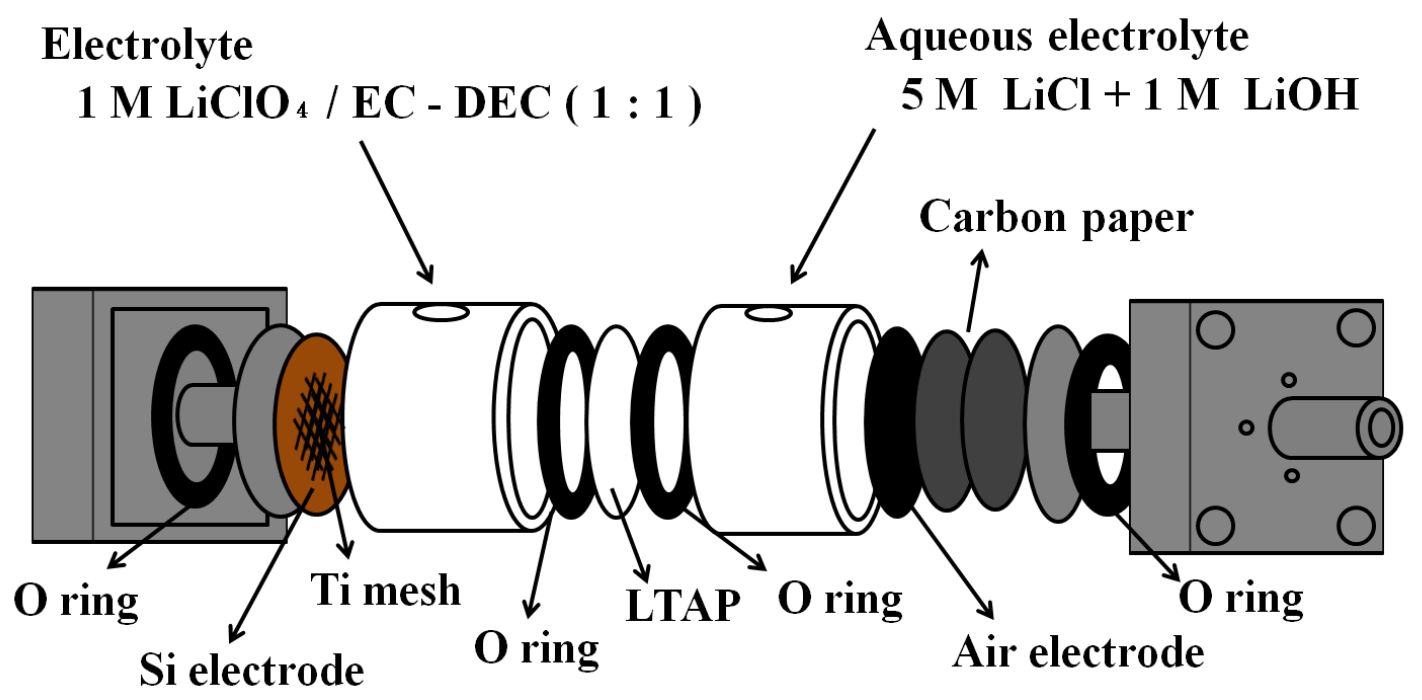


Fig. 2

(a)

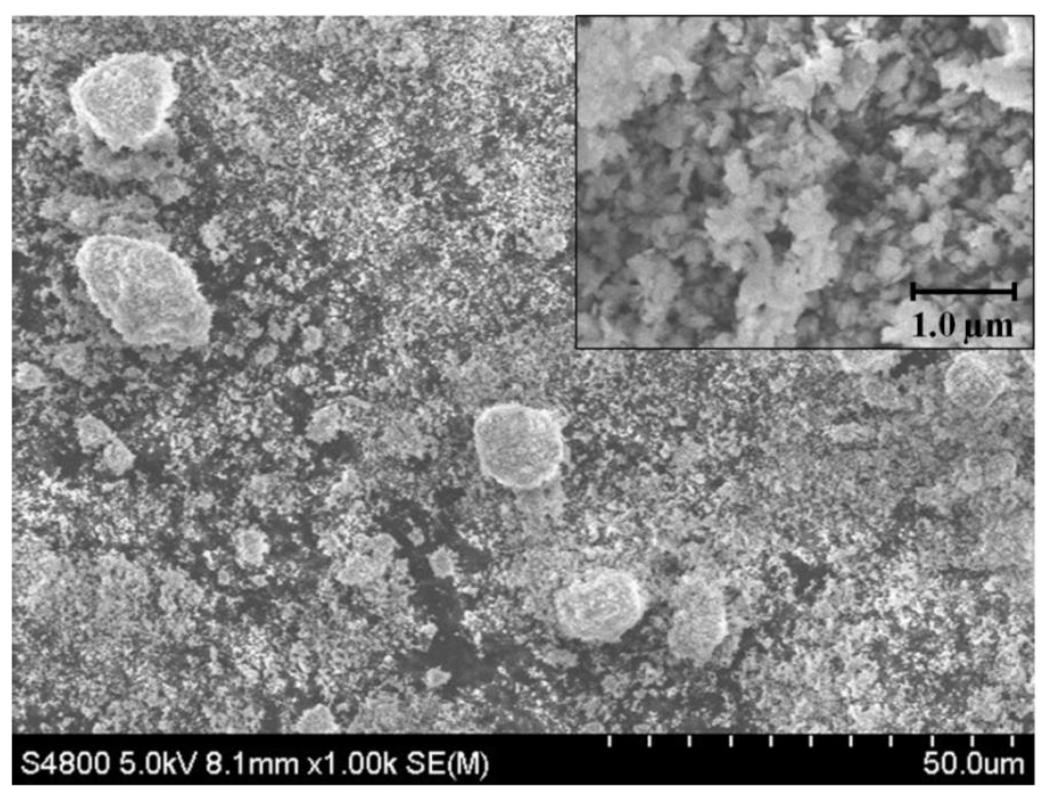

(b)

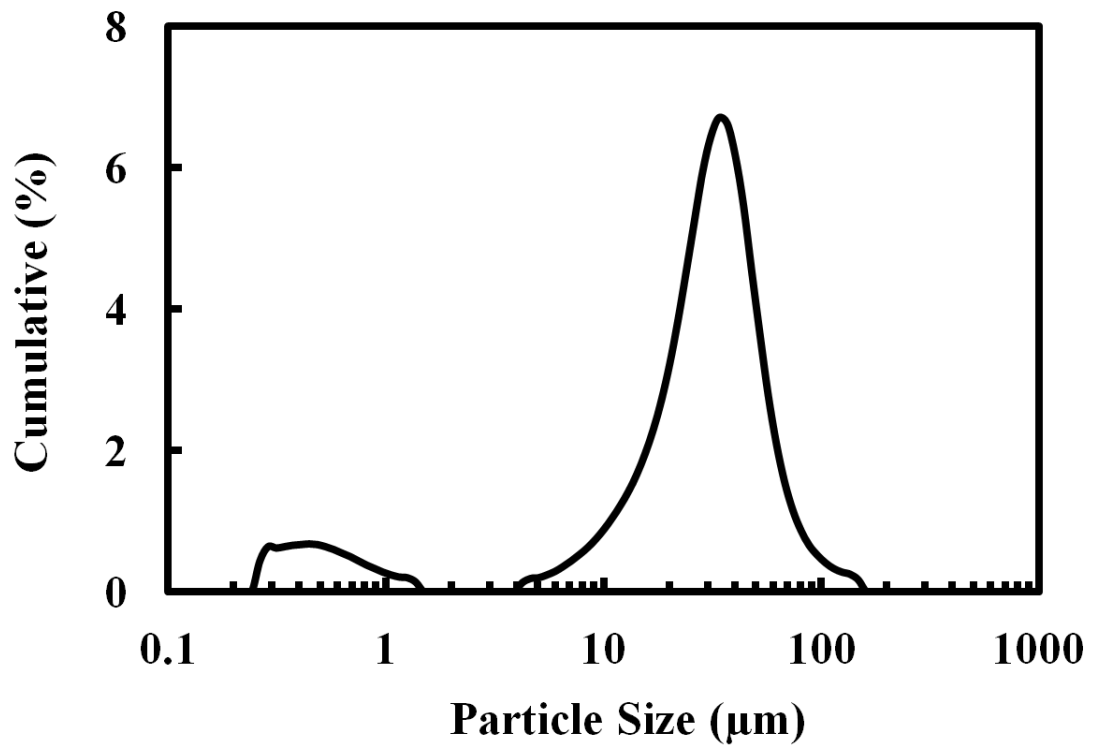


Fig. 3

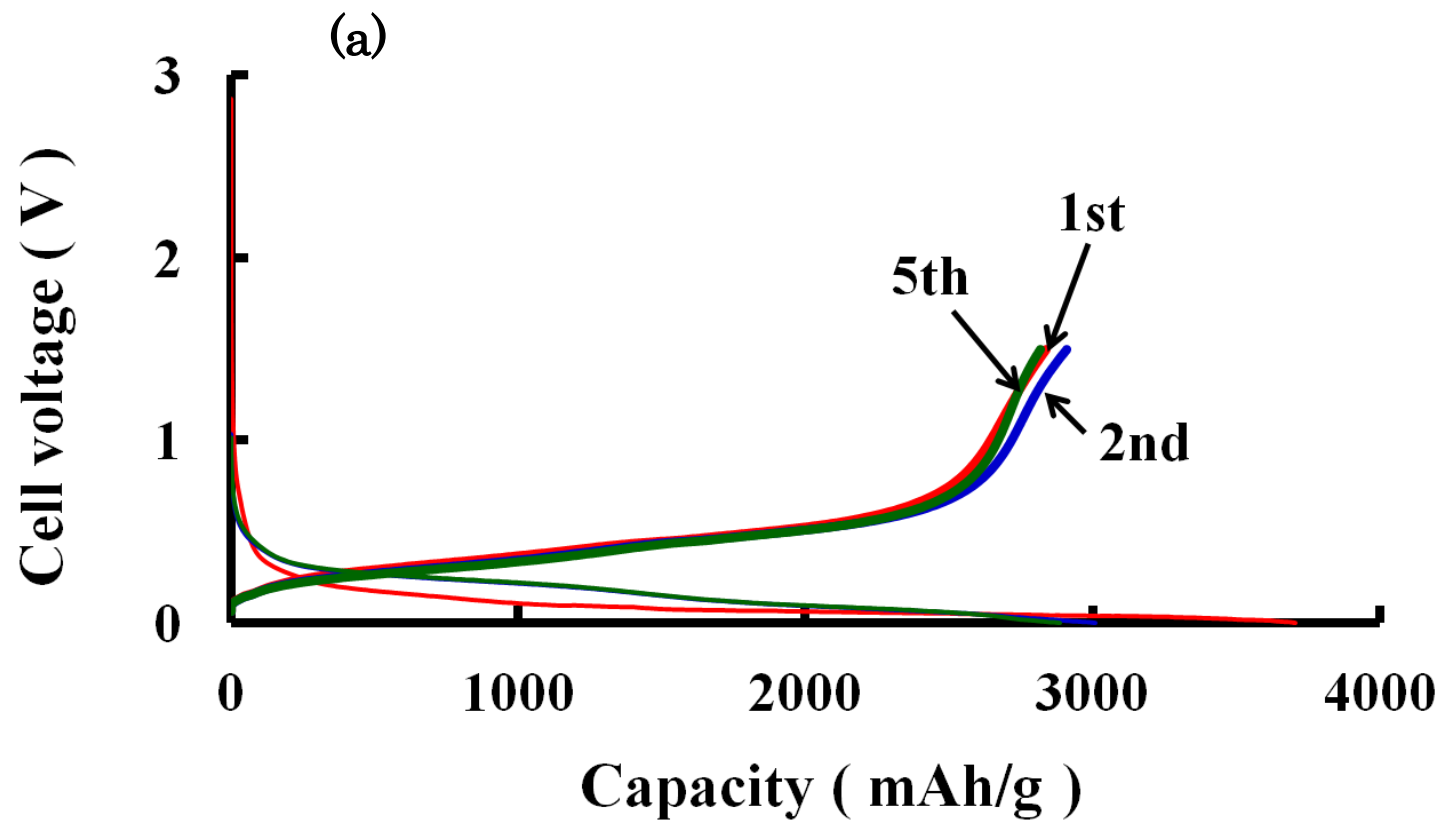

(b)

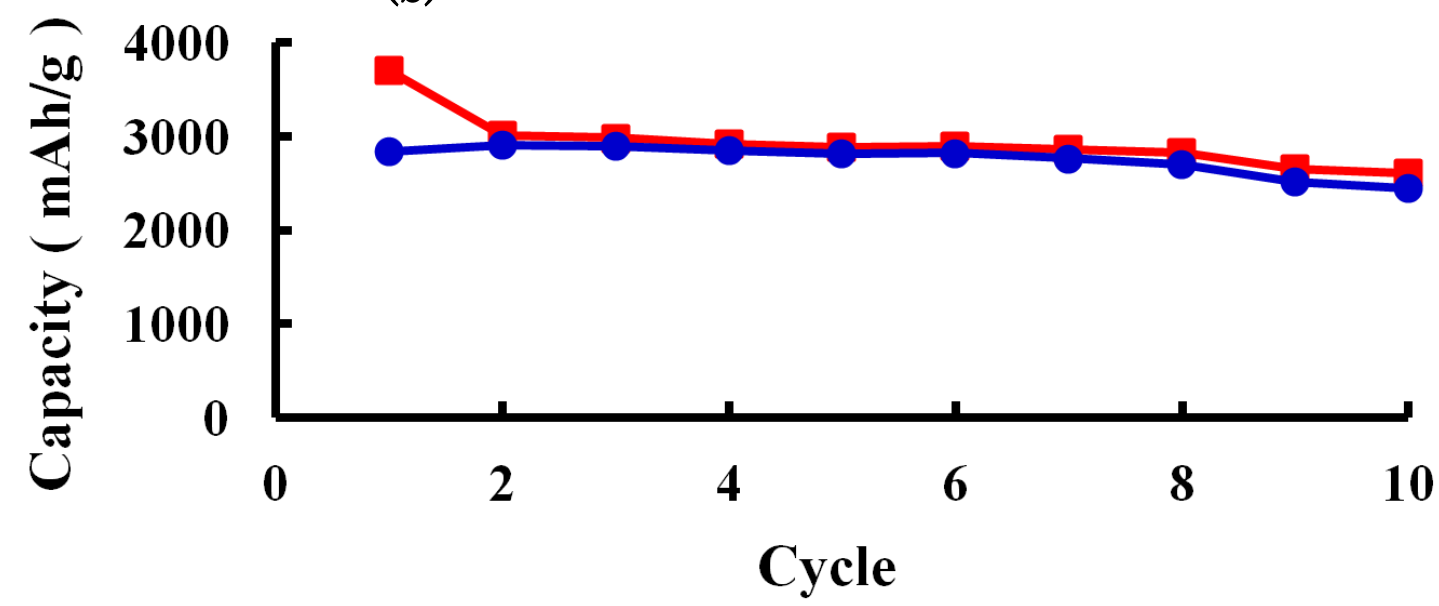


Fig. 4

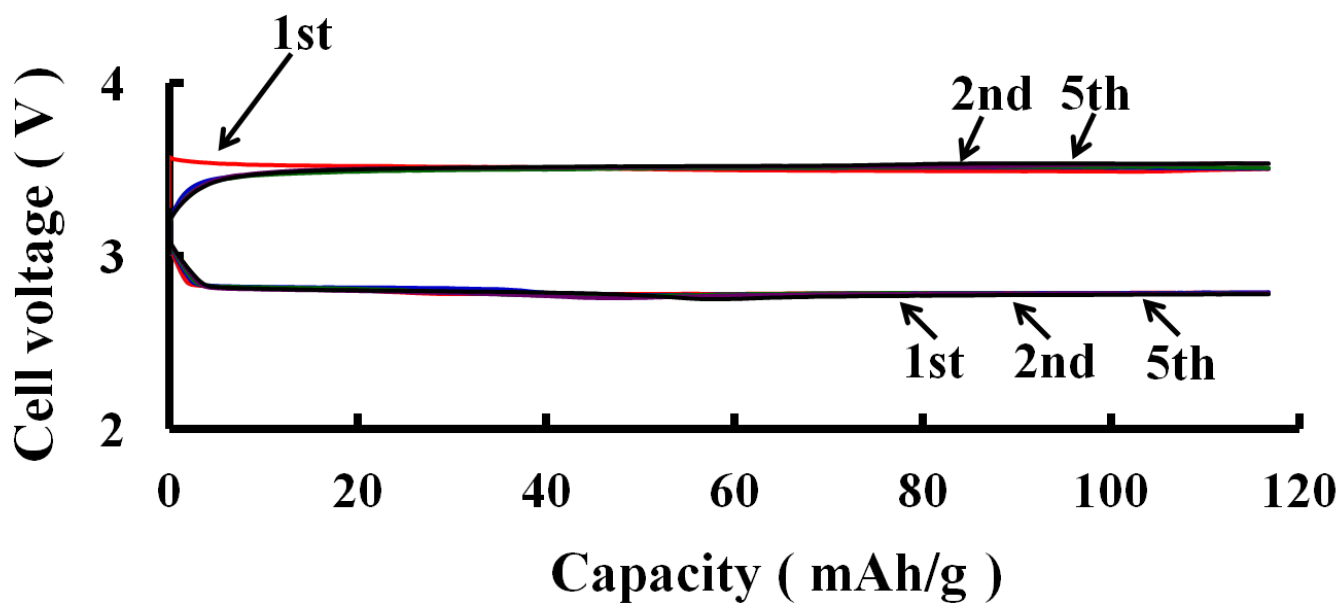


Fig. 5

(a)

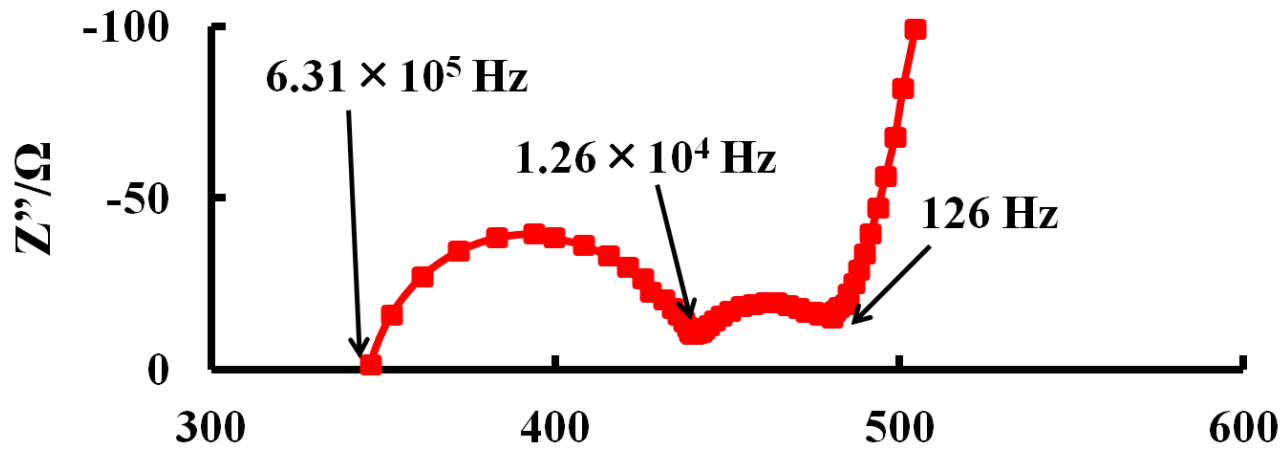

(b)

Z'/ $\mathbf{\Omega}$

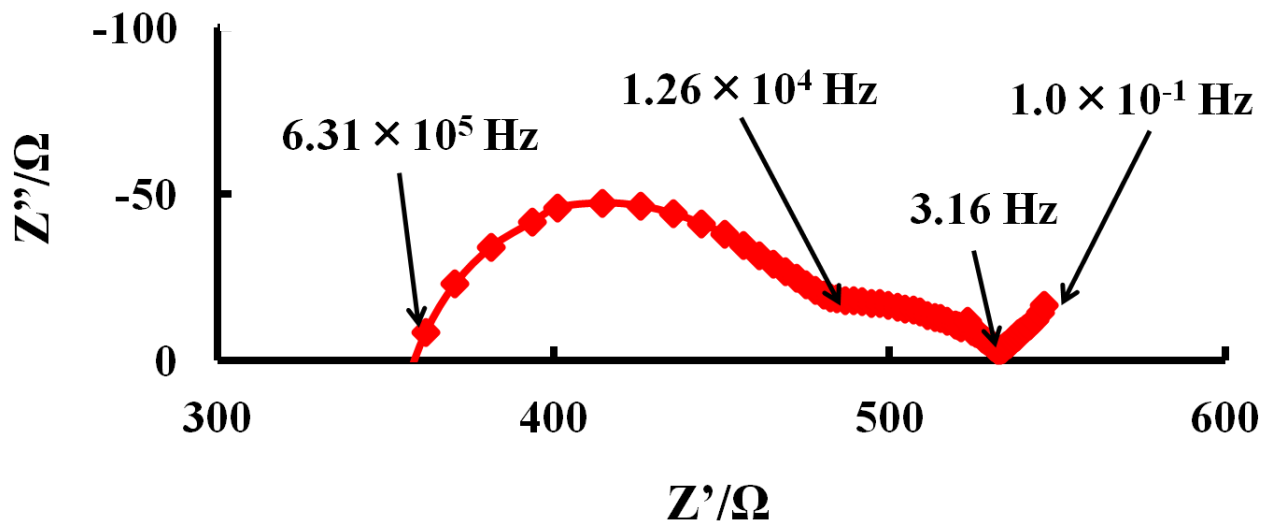

(c)

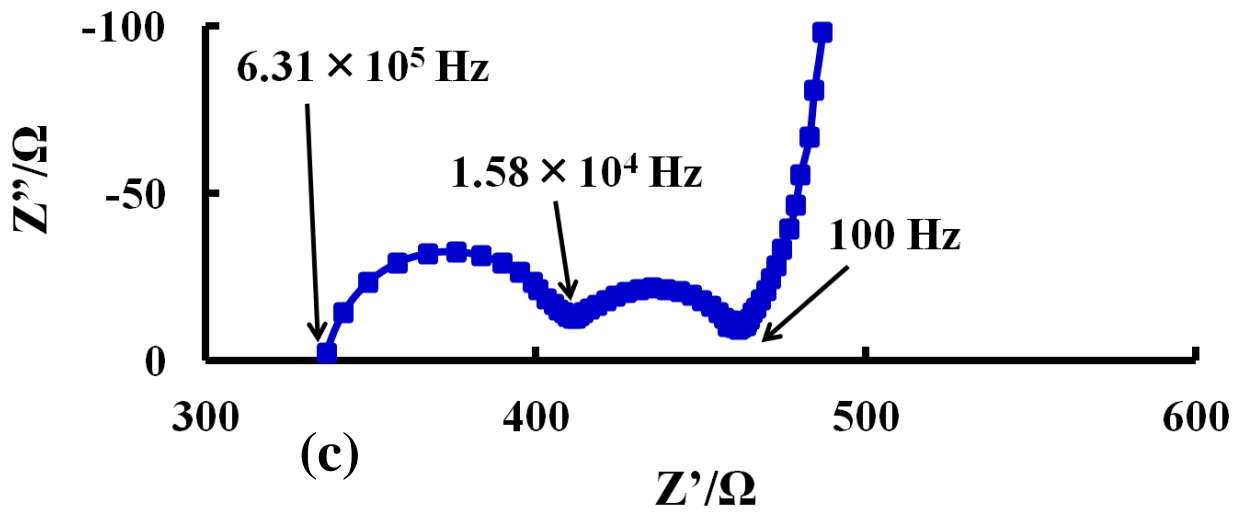


Fig. 6

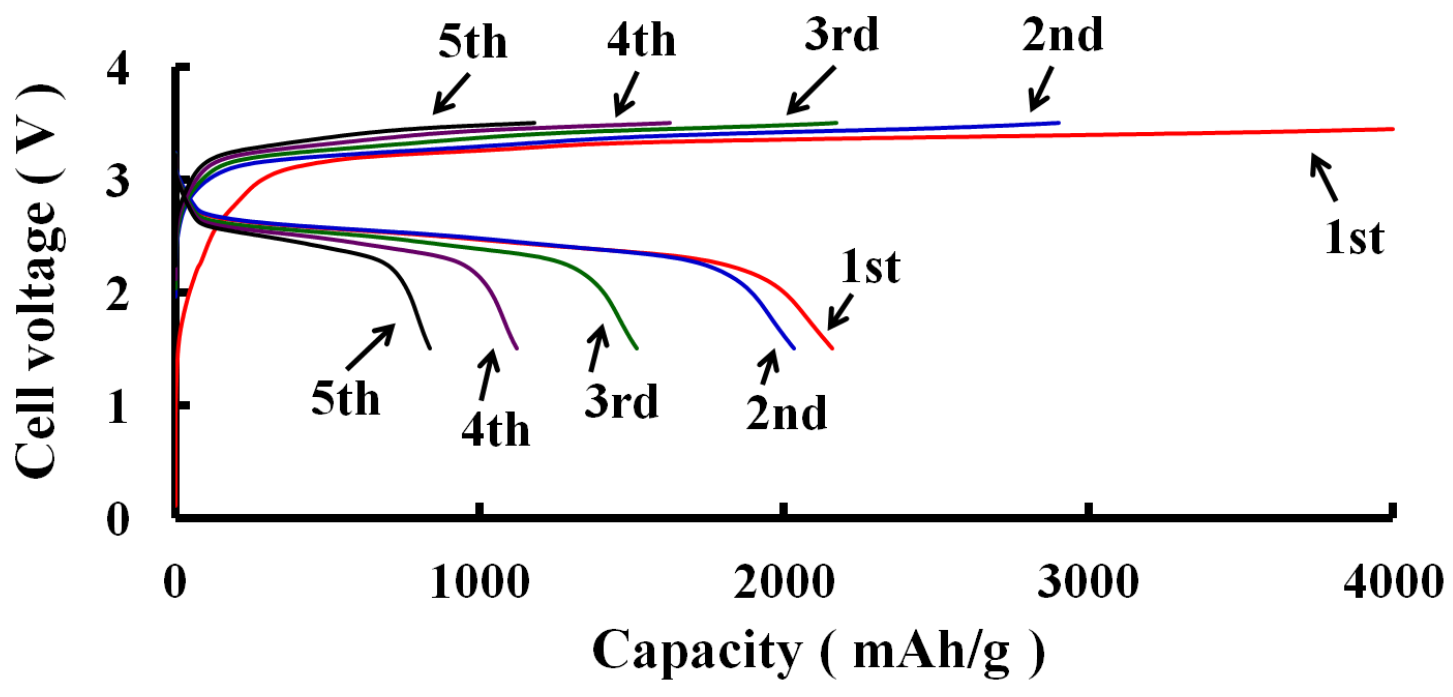


Fig 7

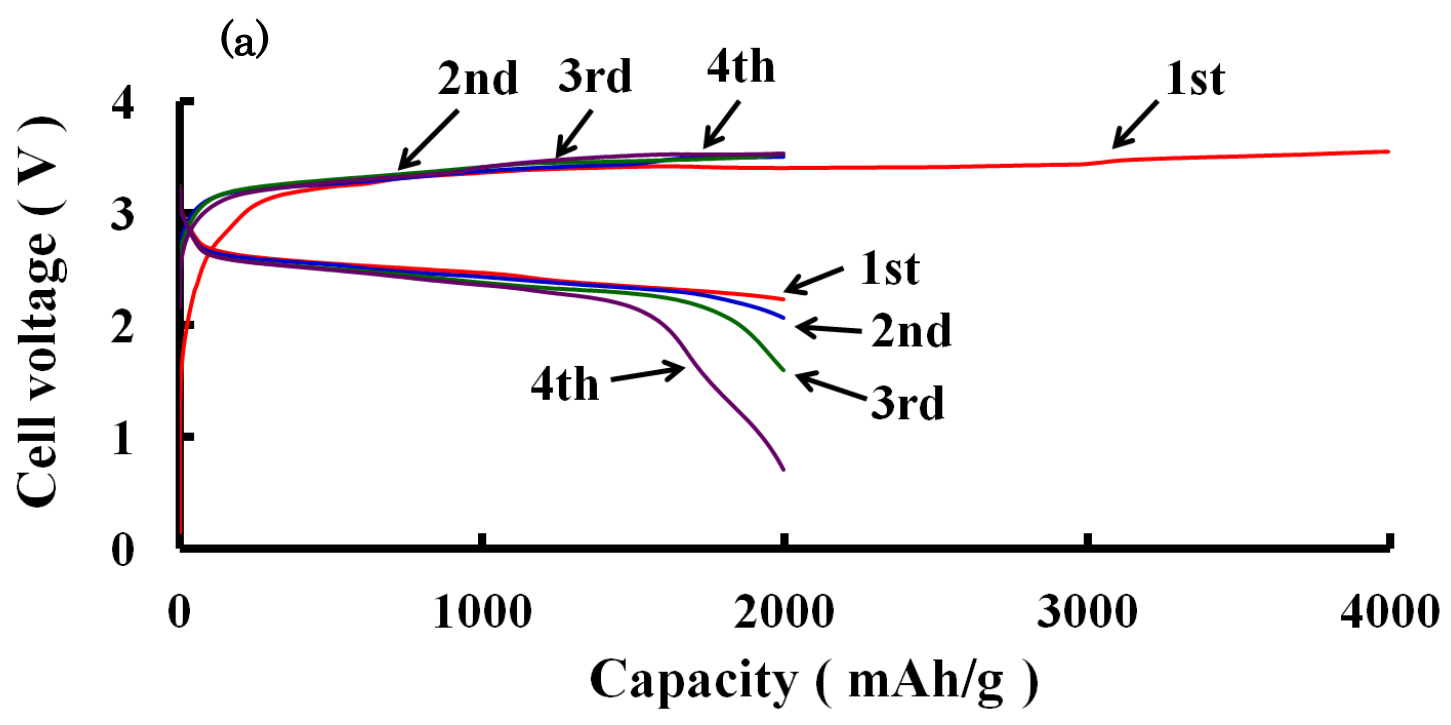

(b)

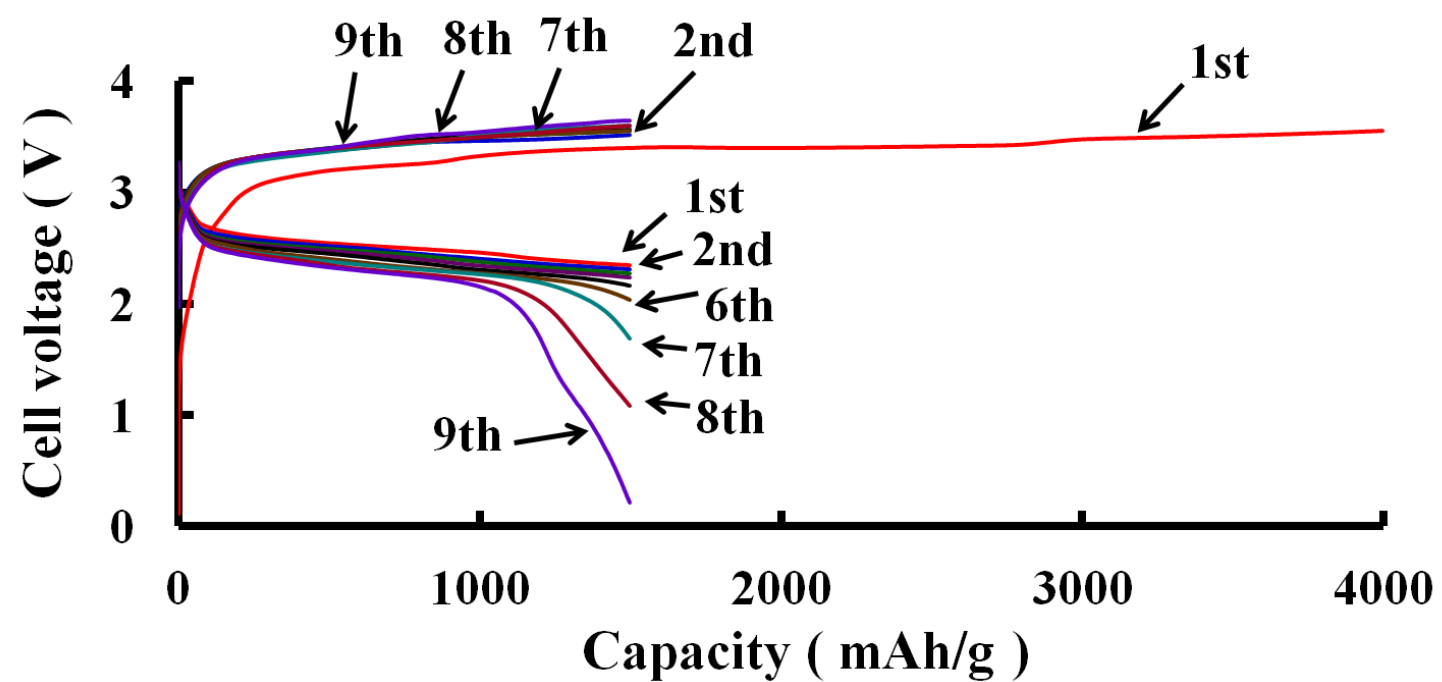



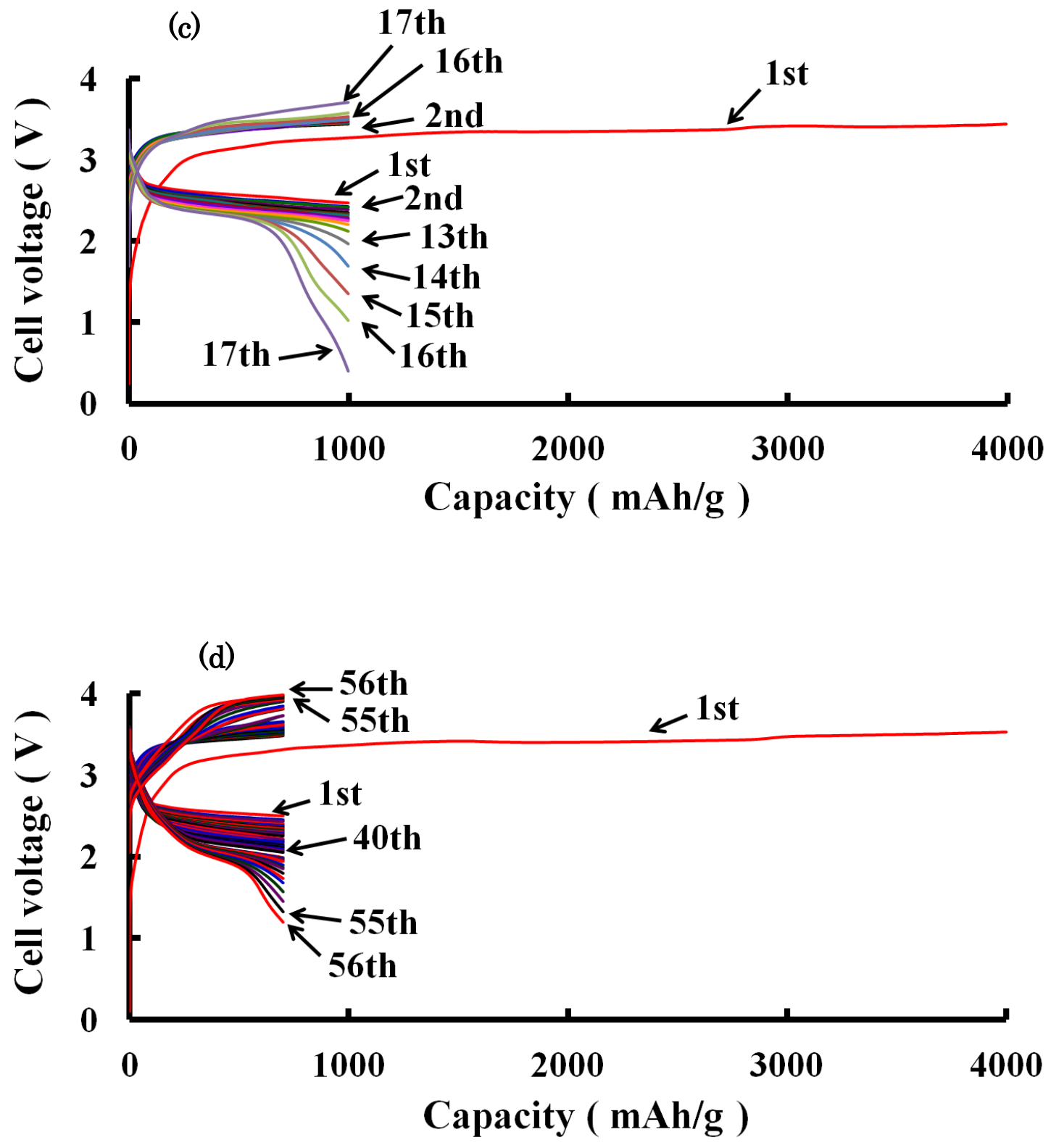
Fig. 8

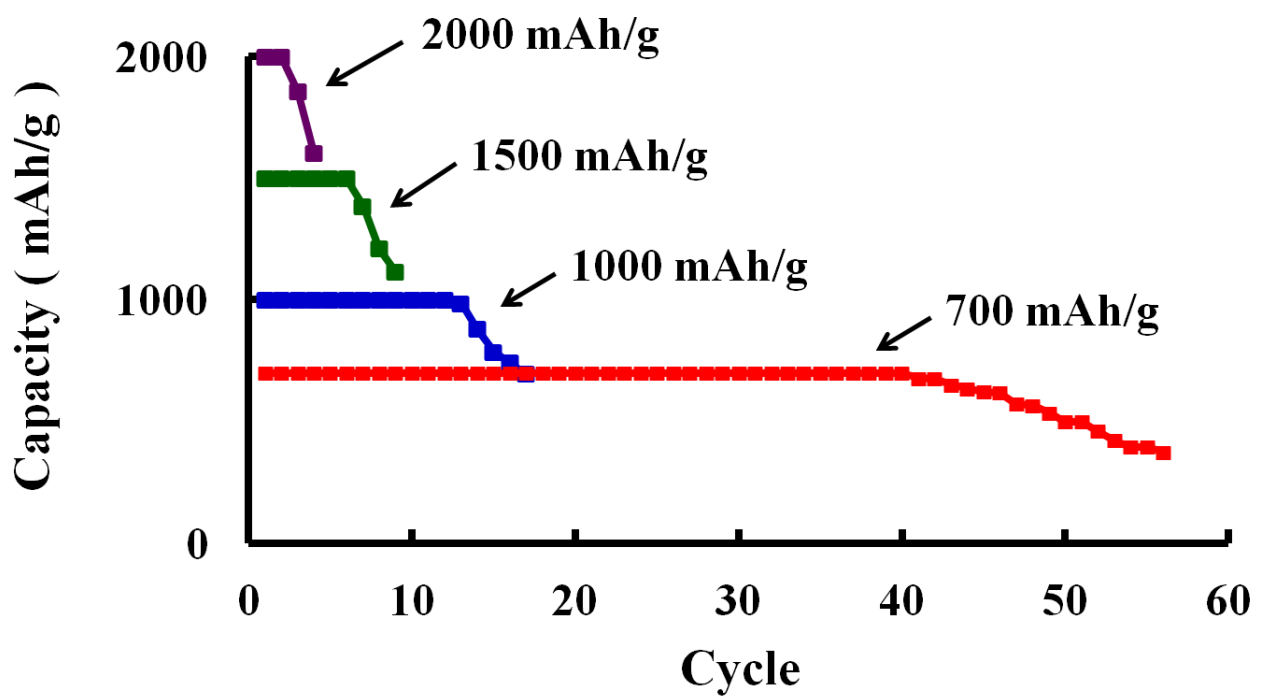

